\title{
MODELING OF PROTEIN AND SALT REDISTRIBUTION DURING DRYING OF A SOLUTION FROM A SQUARE CELL
}

\author{
D.M. Glibitskiy \\ O. Ya. Usikov Institute for Radiophysics and Electronics of the National Academy of Sciences of Ukraine, \\ 12, Acad. Proskura St., 61085, Kharkiv 61022, Ukraine \\ e-mail: dima.glib@gmail.com \\ Submitted April 1, 2018 \\ Accepted April 10, 2018
}

Background: Drying of biological fluids and saline biopolymer solutions is an actively researched topic, since the textures of the films remaining on the substrate after evaporation carry information about the state of the organism or biopolymer. Earlier, we have shown that the texture area and the amount of zigzag crystallization patterns depend on the structural state of the biopolymer. Models of flows and particle redistribution in a round sessile drop have been described by multiple authors, but in our experiments the solution completely fills a square cell to its walls, which results in different drying conditions and dynamics.

Objectives: Conducting a numerical simulation of liquid evaporation and the corresponding redistribution of BSA and $\mathrm{NaCl}$ particles for a square $20 \times 1 \times 20 \mathrm{~mm}^{3}$ cell.

Materials and methods: Liquid evaporation was simulated in the OpenFOAM continuous media modeling package using the interThermalPhaseChangeFoam module, and the redistribution of the particle concentrations (BSA, $\mathrm{Na}^{+}$and $\mathrm{Cl}^{-}$) in the solution was simulated using the method of biased random walk on a discrete Cartesian lattice.

Results: According to the obtained results, for most of the drying time, the flows in the liquid are from the corners to the center of the cell and from the diagonals to the walls of the cell, which leads to the accumulation of a significant fraction of the particles near the walls. When the liquid-air interface in the central part of the cell reaches the bottom, the surface tension forces quickly withdraw the solution to the cell walls, although a small amount of liquid can remain as a drop in the center. After complete drying, the majority of BSA and $\mathrm{NaCl}$ particles that did not settle at the cell walls were found to be concentrated at a distance of 1-3 mm from the cell walls, in the form of a rounded band. A small amount of BSA is also present in the central part of the cell, while the remainder of the salt is uniformly distributed over the entire area of the cell due to its greater diffusivity.

Conclusions: Taking into account the experimental distributions of textures, these results support the hypotheses that textures are not formed in the absence of a biopolymer, and that zigzag patterns are formed in locations with high drying rate.

KEY WORDS: evaporation; modeling; protein; salt; square cell.

\section{МОДЕЛЮВАННЯ ПЕРЕРОЗПОДІЛУ БІЛКА І СОЛІ ПРИ ВИСУШУВАННІ РОЗЧИНУ 3 КВАДРАТНОЇ КЮВЕТИ Д.М. Глибицький \\ Інститут радіофізики та електроніки ім. О. Я. Усикова НАН Украӥни, вул. Ак. Проскури 12, м. Харків, 61085, Україна}

Актуальність. Висихання біологічних рідин та сольових розчинів біополімерів $є$ активно досліджуваною темою, оскільки текстури плівок, що залишаються на підложці після випаровування, несуть інформацію про стан організму або біополімера. В наших попередніх роботах було показано, що площа текстур та здатність до формування зигзагоподібних патернів кристалізації залежать від структурного стану біополімера. Моделювання течій та перерозподілу часток для стандартного випадку круглої сидячої краплі проводилося багатьма авторами, але в наших експериментах розчин повністю заповнює квадратну кювету до рівня іiі стінок, що створює інші умови випаровування та хід процесу висихання.

Мета роботи. Провести чисельне моделювання випаровування рідини та викликаного ним руху частинок БСА і $\mathrm{NaCl}$ для квадратної кювети $20 \times 1 \times 20 \mathrm{Mм}^{3}$.

Матеріали і методи. Моделювання випаровування рідини здійснювалося у пакеті моделювання суцільних середовищ OpenFOAM із застосуванням модулю interThermalPhaseChangeFoam, a

(C) Glibitskiy D.M., 2018 
перерозподіл концентрацій часток (БСА, $\mathrm{Na}^{+} \mathrm{i} \mathrm{Cl}^{-}$) у розчині моделювався методом зміщеного випадкового блукання на дискретній Декартовій решітці.

Результати. Згідно з отриманими результатами, впродовж основного часу сушки течії у рідині направлені від кутів до центра кювети та від діагоналей до стінок кювети, що призводить до накопичення значної долі частинок біля стінок. Коли поверхня рідини у центральній частині кювети торкається дна, сили поверхневого натягу швидко відтягують розчин до стінок кювети, хоча невелика кількість рідини може залишитися у центрі у вигляді краплі. Після повного висихання, основна кількість частинок БСА і NaCl, що не осіла біля стінок кювети, виявилася зосередженою на відстані 1-3 мм від країв кювети у вигляді закругленої смуги. Невелика кількість БСА також присутня у центральній частині кювети, тоді як решта солі рівномірно розподілена по всій площі кювети завдяки більшій дифузивності.

Висновки. Беручи до уваги експериментальні розподіли текстур, ці результати свідчать на користь гіпотез, що текстури не утворюються за відсутності біополімера, а зигзагоподібні патерни формуються у ділянках з високою швидкістю висушування.

КЛЮЧОВІ СЛОВА: випаровування; моделювання; білок; сіль; квадратна кювета.

\title{
МОДЕЛИРОВАНИЕ ПЕРЕРАСПРЕДЕЛЕНИЯ БЕЛКА И СОЛИ ПРИ ВЫСУШИВАНИИ РАСТВОРА ИЗ КВАДРАТНОЙ КЮВЕТЫ
} Д.М. Глибицкий

Институт радиофизики и электроники им. А. Я. Усикова НАН Украинь, ул. Ак. Проскуры 12, г. Харьков, 61085, Украина

\begin{abstract}
Актуальность. Высыхание биологических жидкостей и солевых растворов биополимеров активно исследуемая область, так как текстуры пленок, остающиеся на подложке после испарения, несут информацию о состоянии организма или биополимера. Ранее нами было показано, что площадь текстур и способность к формированию зигзагоподобных паттернов кристаллизации зависят от структурного состояния биополимера. Моделирование течений и перераспределения частиц для стандартного случая круглой сидячей капли проводилось многими авторами, но в наших экспериментах раствор полностью заполняет квадратную кювету до уровня ее стенок, что создает другие условия испарения и ход процесса высыхания.
\end{abstract}

Цель работы. Провести численное моделирование испарения жидкости и вызванного им движения частиц БСА и $\mathrm{NaCl}$ для квадратной кюветы $20 \times 1 \times 20 \mathrm{mм}^{3}$.

Материалы и методы. Моделирование испарения жидкости выполнялось в пакете моделирования сплошных сред ОреnFОАМ с применением модуля interThermalPhaseChangeFoam, а перераспределение концентраций частиц (БСА, $\mathrm{Na}^{+}$и $\mathrm{Cl}^{-}$) в растворе моделировалось методом смещенного случайного блуждания на дискретной Декартовой решетке.

Результаты. Согласно полученным результатам, в течение основного времени сушки течения в жидкости направлены от углов к центру кюветы и от диагоналей к стенкам кюветы, что приводит к накоплению значительной доли частиц у стенок. Когда поверхность жидкости в центральной части кюветы касается дна, силы поверхностного натяжения быстро оттягивают раствор к стенкам кюветы, хотя небольшое количество жидкости может остаться в центре в виде капли. После полного высыхания, основное количество частиц БСА и $\mathrm{NaCl}$, которое не осело у стенок кюветы, оказалось сосредоточенным на расстоянии 1-3 мм от краев кюветы в виде закругленной полосы. Небольшое количество БСА также присутствует в центральной части кюветы, тогда как остаток соли равномерно распределен по всей площади кюветы из-за большей диффузивности.

Выводы. Принимая во внимание экспериментальные распределения текстур, эти результаты свидетельствуют в пользу гипотез, что текстуры не образуются при отсутствии биополимера, а зигзагоподобные паттерны формируются на участках с высокой скоростью сушки.

КЛЮЧЕВЫЕ СЛОВА: испарение; моделирование; белок; соль; квадратная кювета.

Evaporation of colloidal solutions has promising applications in a number of industries, such as medicine [1-3], agriculture [4, 5] and microelectronics [6, 7]. Films obtained as a result of the evaporation of biological fluids or saline solutions of biopolymers were investigated by various authors [8-14]; in particular, our experiments have shown that the structural state of the biopolymer affects the area of visible textures [15] and the number of zigzag crystallization patterns on the film [16-18].

Mechanisms of drying of colloid-salt solution droplets, as well as mechanisms of pattern formation on the resulting films, are an actively studied subject [19-24]. However, instead of the standard method of sessile droplet evaporation, we use a flat cell filled with solution to 
Modeling of protein and salt redistribution during drying of a solution from a square cell

improve reproducibility of the contours and the areas of the obtained films. This changes the evaporation conditions and the course of drying compared to the free drop, which does not let us draw direct analogies with the existing models of particle redistribution in the drying droplet. Due to the fact that the geometry of our cell (square $20 \times 20 \mathrm{~mm}^{2}$ cell with $1 \mathrm{~mm}$ high walls) cannot be reduced to an axially symmetric $2 \mathrm{D}$ case, the theoretical analysis of the problem is considerably complicated; therefore, in this study we conducted a numerical simulation of fluid evaporation and of the corresponding particle motion for a square cell.

\section{MODEL}

As a first approximation, the following assumptions were made during the simulation:

1. Available concentrations of protein and salt do not affect the overall course of hydrodynamics and evaporation: for most of the drying time, the mass fraction of BSA (bovine serum albumin) and $\mathrm{NaCl}$ in the solution is very low (about $0.2-2 \%$ ), so their effect on viscosity, thermal conductivity, surface tension, and other physical and chemical properties of the solvent can be considered negligible; accordingly, liquid evaporation can be simulated separately from particle redistribution.

2. Inhibition of the Marangoni effect: although in theory the contribution of the Marangoni flows must be noticeable in evaporating droplets of pure water, in practice their effect is very weak due to residual contamination by surface-active substances [25].

3. The effect of contact line pinning is ignored (due to the complexity of modeling this phenomenon in the OpenFOAM package).

4. Absence of particle aggregation: the present concentration of $\mathrm{NaCl}$ salt is not large enough to completely compensate the charge of BSA, so during the simulation it was assumed that protein molecules effectively do not aggregate.

\section{Simulation of fluid evaporation in a square cell}

The simulation of fluid evaporation was performed in the OpenFOAM continuous media finite element modeling package. For hydrodynamic problems with two phases this package uses a volume-of-fluid method, where the amount of liquid in each spatial element of the computational domain is represented by the "volume-of-fluid" quantity $\alpha$. To model the phenomena of mass and heat transport, surface tension and phase transition, the interThermalPhaseChangeFoam module [26, 27] was used, which solves the conservation equations for mass (using the Poisson equation), momentum (taking into account viscous forces, pressure, surface tension and gravity), thermal energy (taking into account the convection and heat conduction phenomena) and volume-of-fluid (with corrections to compress the interface and counteract numerical diffusion).

The cells we use for obtaining films have a volume of 20x1 $20 \mathrm{~mm}^{3}$. Since the initial volume of the solution is $0.5 \mathrm{ml}$, the height of the liquid can reach $1.3 \mathrm{~mm}$, so an additional $1 \mathrm{~mm}$ of air above the cell was included in the computational domain. To accelerate the simulation, the domain was limited to a rectangular volume of $10 \times 2 \times 10 \mathrm{~mm}^{3}$ along the axes $\mathrm{X}, \mathrm{Y}$ and $\mathrm{Z}$, respectively (Fig. 1), which corresponds to a quarter of the cell. This volume was divided into cubic $0.1 \times 0.1 \times 0.1 \mathrm{~mm}^{3}$ finite elements in the form of a three-dimensional grid $(100 \times 20 \times 100$ elements along the corresponding axes).

To assign the boundary conditions, the surface of the computational domain was divided into 4 areas: the XY side, the YZ side, the surface below $1 \mathrm{~mm}$ ("cell") and the surface above $1 \mathrm{~mm}$ ("air"). The boundary conditions for these areas are given in the Table 1. 


\section{D.M. Glibitskiy}

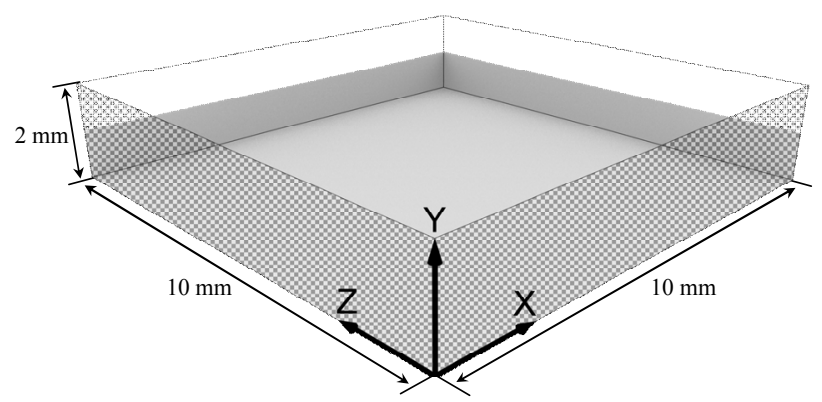

Fig. 1. The computational domain and the coordinate system used in the calculations.

Table 1. Boundary conditions for the values used in modeling of evaporation. $\nabla_{\vec{N}}$ denotes the gradient in the direction normal to the boundary surface. The value of the wetting angle was taken from [28], the temperature corresponds to the experimental values $[16,17]$, and the rest of the boundary conditions were chosen in accordance with the conventional practices [29]

\begin{tabular}{|l|l|l|l|}
\hline \multicolumn{1}{|c|}{ "Cell" area } & \multicolumn{1}{c|}{ "Air" area } & \multicolumn{1}{c|}{ XY and YZ sides } \\
\hline Volume-of-fluid $\alpha$ & Wetting angle $=36.7^{\circ}$ & $\begin{array}{l}\text { Outside: } \nabla_{\bar{N}} \alpha=0 ; \\
\text { inside: } \alpha=0\end{array}$ & Symmetry planes \\
\hline Enthalpy $H$ & $\nabla_{\bar{N}} H=0$ & $\nabla_{\bar{N}} H=0$ & Symmetry planes \\
\hline $\begin{array}{l}\text { Difference between static } \\
\text { and hydraulic pressure } \\
p-\rho g h\end{array}$ & $\nabla_{\bar{N}}(p-\rho g h)=0$ & $p-\rho g h=0$ & Symmetry planes \\
\hline Velocity $\vec{U}$ & $\vec{U}=(0,0,0)$ & $\nabla_{\bar{N}} \vec{U}=0$ & Symmetry planes \\
\hline Temperature $T$ & $T=40^{\circ} \mathrm{C}$ & $T=40^{\circ} \mathrm{C}$ & Symmetry planes \\
\hline
\end{tabular}

Initial values for the fields $H, p-\rho g h, \vec{U}$ and $T$ for the whole domain were initialized as $0 \mathrm{~J}, 0 \mathrm{~Pa}, 0 \mathrm{~m} / \mathrm{s}$ and $40{ }^{\circ} \mathrm{C}$, respectively.

In our experiments, it was observed that after $t_{\exp }=20 \mathrm{~min}$ in the drying chamber, $0.060 \pm 0.003 \mathrm{~g}$ of a solution evaporates from the cell, and $0.224 \pm 0.003 \mathrm{~g}$ after $t_{\text {exp }}=80 \mathrm{~min}$. Correspondingly, $0.5 \mathrm{ml}$ of a solution completely evaporates in 3 hours on average.

Due to the simulation taking a lot of time to compute, it was decided to start with $0.333 \mathrm{ml}$ of water (which corresponds to $t_{\exp }=1$ hour). Assuming that the nature of the currents within the liquid stays the same for most of the drying time, this shouldn't significantly affect the final deposition distributions. To account for the liquid meniscus, which forms near the cell walls due to surface tension, the field $\alpha$ was initialized using the formula (1)

$$
\begin{gathered}
\alpha(x, y, z)=\min \left(\max \left((h(x, z)-y) / L_{E}+0.5,0\right), 1\right), \\
h(x, z)=h_{C}-\left(h_{C}-h_{W}\right) \cdot \min \left(\left(w_{C / 2}-\max (|x|,|z|)\right) / w_{M}, 1\right)^{P},
\end{gathered}
$$

where $L_{E}=0.1 \mathrm{~mm}$ is the size of the finite element, $h_{C}=1 \mathrm{~mm}$ is the height of the cell walls, $w_{C / 2}=10 \mathrm{~mm}$ is the half-width of the cell; the rest of the parameters were chosen empirically to approximate the surface of $0.333 \mathrm{ml}$ of liquid: $h_{W}=0.75 \mathrm{~mm}$ (height of the liquid at the cell center), $w_{M}=3.5 \mathrm{~mm}$ (width of the meniscus), $P=1 / 3$ (empirical coefficient determining the shape of the meniscus). The $\min ()$ and $\max ()$ denote the minimum and maximum of a set of values, respectively (the same notation is used throughout the paper). 
Modeling of protein and salt redistribution during drying of a solution from a square cell

The simulation was performed using the incompressible Newtonian fluid and laminar flow approximations, the Brackbill surface tension model [30] and the "Interface Equilibrium - No Dilatation" phase change model [26]. The properties of the liquid and gaseous phases that were used in the simulation are given in the Table 2.

Table 2. Physical properties of water and its vapor at $40{ }^{\circ} \mathrm{C}$

\begin{tabular}{|l|c|c|}
\hline Kinematic viscosity of water, $\mathrm{m}^{2} / \mathrm{s}$ & $0.658 \cdot 10^{-6}$ & {$[31]$} \\
\hline Density of water, $\mathrm{kg} / \mathrm{m}^{3}$ & 992 & {$[31]$} \\
\hline Thermal conductivity of water, $\mathrm{W} /(\mathrm{m} \cdot \mathrm{K})$ & 0.631 & {$[31]$} \\
\hline Specific heat of water, $\mathrm{J} / \mathrm{kg} \cdot \mathrm{K})$ & 4178 & {$[31]$} \\
\hline Kinematic viscosity of water vapor, $\mathrm{m}^{2} / \mathrm{s}$ & $20.5 \cdot 10^{-6}$ & {$[31]$} \\
\hline Density of water vapor, $\mathrm{kg} / \mathrm{m}^{3}$ & 0.598 & {$[31]$} \\
\hline Thermal conductivity of water vapor, $\mathrm{W} /(\mathrm{m} \cdot \mathrm{K})$ & 0.025 & {$[31]$} \\
\hline Specific heat of water vapor, $\mathrm{J} /(\mathrm{kg} \cdot \mathrm{K})$ & 2077 & {$[31]$} \\
\hline Surface tension, $\mathrm{kg} / \mathrm{s}^{2}$ & 0.0695 & {$[32]$} \\
\hline Phase change enthalpy, $\mathrm{J} / \mathrm{kg}$ & 2264705 & {$[33]$} \\
\hline
\end{tabular}

Since the direction of the phase change (i.e., whether evaporation or condensation takes place) in interThermalPhaseChangeFoam $[26,27]$ is determined by the difference between the temperature of the finite element $T$ and the saturation temperature $T_{\text {sat }}$ of the liquid, we had to set the saturation temperature lower than the temperature of the cell $\left(T_{\text {sat }}=10{ }^{\circ} \mathrm{C}\right.$ to reduce the computational time) and to use a model which did not incorporate formation of vapor bubbles. As a result, the rate of evaporation in the simulation was 2-3 orders of magnitude higher than in the experiment; however, the qualitative nature of the obtained currents can still be useful as a first approximation in particle redistribution modeling. In order to correlate the simulation results with the experiment, simulation time $t_{\text {sim }}$ was matched to the "experimental time" $t_{\text {exp }}$ based on the volume of water remaining in the cell (2):

$$
t_{\exp }=t_{\text {total }}\left(1-\frac{4 V_{E}}{V_{0}} \sum_{i, j, k} \alpha(i, j, k)\right),
$$

where the total drying time $t_{\text {total }}=10800 \mathrm{~s}$, the volume of the finite element $V_{E}=10^{-12} \mathrm{~m}^{3}$, the initial volume of the solution $V_{0}=5 \cdot 10^{-7} \mathrm{~m}^{3},(i, j, k)$ is the three-dimensional index of the corresponding finite element. In the simulation of particle redistribution, velocity values $\vec{U}$ were also scaled accordingly.

\section{Modeling of redistribution of colloidal particles and dissolved salt}

To simulate the particle redistribution in the solution, biased random walk on a discrete Cartesian lattice (with cubical elements) was used, where the probability of particle movement between adjacent lattice cells depends on the vector of fluid velocity (the details are laid out in the "Calculation of the probability of particle motion" section). The same number of elements $(100 \times 20 \times 100)$ was used as the size of the discrete lattice. BSA and salt concentrations were initialized as evenly distributed over the volume of the liquid; assuming that the nature of the currents within the liquid stays the same for most of the drying time, this shouldn't significantly affect the final deposition distributions. 
The algorithm for simulating particle motion was based on the ideas described in [34, 35]. The overall structure of the algorithm is depicted in Fig. 2.

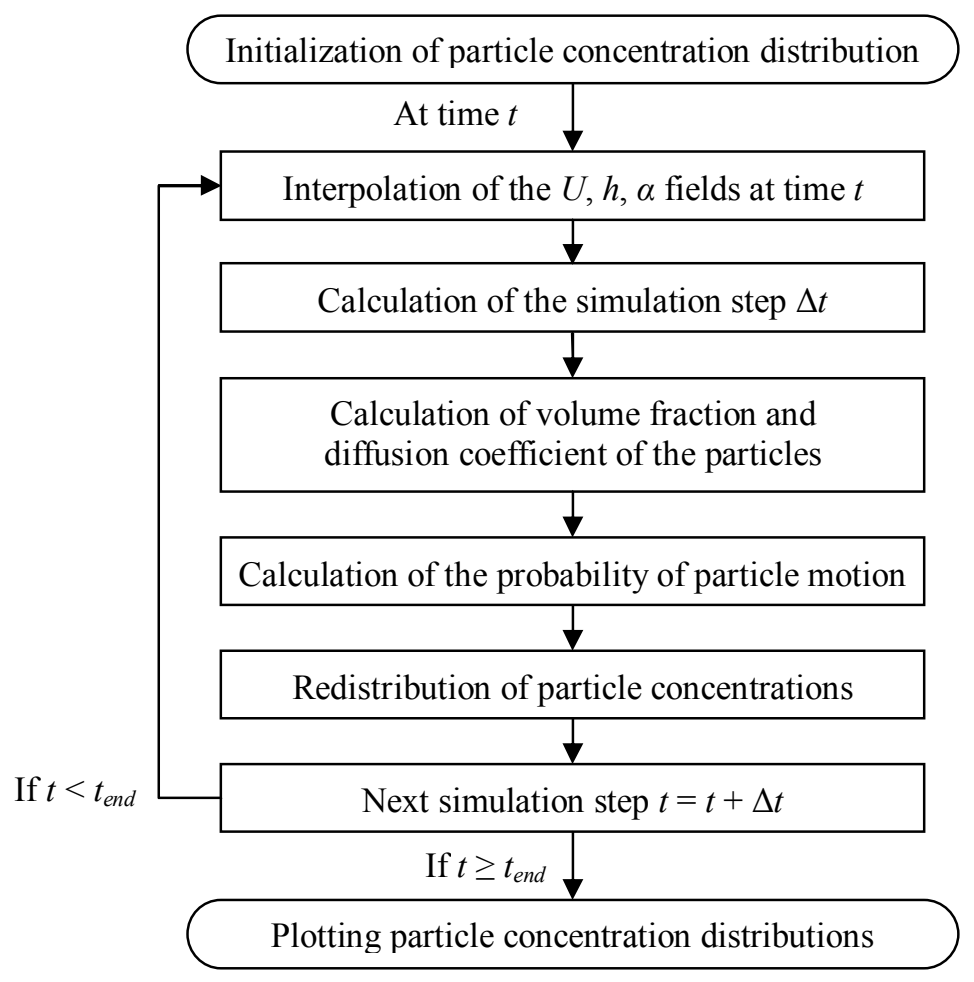

Fig. 2. Block diagram of the algorithm for simulation of particle redistribution.

During the simulation, BSA molecules and dissolved salt ions $\left(\mathrm{Na}^{+}, \mathrm{Cl}^{-}\right)$were considered separate types of particles. Initial concentrations and physical parameters of these particles are shown in Table. 3

Table 3. Parameters of particles used in calculations. For BSA, $r_{p}$ was taken from [36], $V_{p}$ from [37], $m_{p}$ from [38]. For $\mathrm{Na}^{+}$and $\mathrm{Cl}^{-}, r_{p}$ was taken from [39], $V_{p}$ was calculated as the volume of spheres of Van der Waals radius [40], and $m_{p}$ was taken from [41]

\begin{tabular}{|l|l|l|l|}
\hline Parameter & BSA & $\mathbf{N a}^{+}$ & $\mathbf{C l}^{-}$ \\
\hline Concentration $C_{0}, \mathrm{~mol} / \mathrm{m}^{3}$ & $7.5 \cdot 10^{-3}$ & 20 & 20 \\
\hline Stokes radius $r_{p}, \mathrm{~m}$ & $4 \cdot 10^{-9}$ & $1.84 \cdot 10^{-10}$ & $1.21 \cdot 10^{-10}$ \\
\hline Volume $V_{p}, \mathrm{~m}^{3}$ & $8.09 \cdot 10^{-26}$ & $4.90 \cdot 10^{-29}$ & $2.24 \cdot 10^{-29}$ \\
\hline Mass $m_{p}, \mathrm{~kg}$ & $1.10 \cdot 10^{-22}$ & $3.82 \cdot 10^{-26}$ & $5.89 \cdot 10^{-26}$ \\
\hline
\end{tabular}

\section{Interpolation of the $U, h, \alpha$ fields at time $t$}

The fields of velocities $\vec{U}_{t}$ and volume-of-fluid $\alpha_{t}$ at a time $t$ were obtained by linear interpolation of snapshots (3-5), which were recorded at regular intervals during the simulation of fluid evaporation. Since water-air interface can move more than one lattice cell per snapshot, interpolation of the field $\alpha$ was not performed directly. Instead, a height-map $h_{n}$ was constructed for each $\alpha_{n}$ snapshot, and the field $\alpha_{t}$ at time $\mathrm{t}$ was calculated from the interpolated height-map $h_{t}(5)$ : 


$$
\begin{gathered}
\vec{U}_{t}(x, y, z)=(1-\tau) \cdot \vec{U}_{n}(x, y, z)+\tau \cdot \vec{U}_{n+1}(x, y, z), \\
h_{t}(x, z)=(1-\tau) \cdot h_{n}(x, z)+\tau \cdot h_{n+1}(x, z), \\
\alpha_{t}(x, y, z)=\min \left(\max \left(\left(h_{t}(x, z)-y\right) / L_{E}+0.5,0\right), 1\right),
\end{gathered}
$$

where $\vec{U}_{n}, h_{n}$ are snapshots of the velocity field and the height-map at the time $t_{n}$, the interpolation coefficient $\tau=\left(t-t_{n}\right) /\left(t_{n+1}-t_{n}\right)$, the size of the finite element $L_{E}=0.1 \mathrm{~mm}$.

\section{Calculation of the simulation step $\Delta t$}

The simulation of motion of colloidal particles was performed using the $t_{\text {exp }}$ time scale (i.e. it started at $t_{\text {exp }}=1$ hour and ended at $t_{\text {exp }}=3$ hours) and a variable time step.

To ensure the correctness of the calculations, the duration of the simulation step $\Delta t$ must be such that the distance traveled by any particle during the step is not larger than the linear size of the lattice element $L_{E}$ :

$$
\Delta t \cdot U_{\max }<L_{E},
$$

where $U_{\max }$ is the maximum projection of velocity in this simulation step

$$
\begin{gathered}
U_{\text {max }}(i, j, k)=\max \left(\left|U_{x}(i, j, k),\right| U_{y}(i, j, k), \mid U_{z}(i, j, k)\right), \\
U_{\text {max }}=\max \left(U_{\text {max }}(i, j, k): i=1, \ldots, N_{i} ; j=1, \ldots, N_{j} ; k=1, \ldots, N_{k}\right) .
\end{gathered}
$$

It was decided to limit the maximal particle distance per step to $1 / 3$ of lattice element size, as a compromise between the simulation fidelity and the time spent on computation. Correspondingly,

$$
\Delta t=\frac{1}{3} \frac{L_{E}}{U_{\max }} .
$$

\section{Calculation of volume fraction and diffusion coefficient of the particles}

Each element of the lattice may contain colloidal particles (BSA) and ions of dissolved salt $\left(\mathrm{Na}^{+}, \mathrm{Cl}^{-}\right)$. In contrast to the papers [34,35], the number of particles in this case is too large for them to be modeled individually. Thus particle movement was simulated as the redistribution of the amount of substance between the adjacent lattice elements.

If we consider colloidal (BSA) and dissolved $\left(\mathrm{Na}^{+}, \mathrm{Cl}^{-}\right)$particles to be solid spheres, their amount in the lattice element is limited by the condition

$$
\phi_{\text {total }}(i, j, k)<\phi_{\max } \text {. }
$$

where $\phi_{\text {total }}(i, j, k)$ is the total volume fraction in the lattice element $(i, j, k), \phi_{\max }$ is the maximum packing fraction. When $\phi_{\text {total }}$ approaches $\phi_{\max }$, the particles within the element (BSA, $\mathrm{Na}^{+}, \mathrm{Cl}^{-}$) are packed so densely that their movement becomes virtually impossible.

The total volume fraction is the sum of volume fractions $\phi_{p}(i, j, k)$ of each type of particle $p$

$$
\phi_{\text {total }}(i, j, k)=\sum_{p} \phi_{p}(i, j, k)
$$

$\phi_{p}(i, j, k)$, in turn, is calculated as 


$$
\phi_{p}(i, j, k)=n_{p}(i, j, k) \cdot N_{A} \cdot V_{p} / V_{E},
$$

where $n_{p}(i, j, k)$ is the amount of substance of particles of type $p$ in the corresponding lattice element, $N_{A}$ is the Avogadro number, $V_{p}$ is the volume of a particle of type $p, V_{E}$ is the volume of the lattice element.

The value of $\phi_{\max }$ is determined by the packing geometry, which depends on the shape and size distribution of the particles, but not on the particle size. For solid spheres, the theoretical value is usually taken $\phi_{\max }=0.64$ [42], which corresponds to random close packing. However, according to the experimental studies of solid sphere dispersions [43, 44], molecular mobility disappears when the volume fraction reaches the value of colloidal glass transition $\phi_{g}[43,44]$. For monodisperse solid spheres $\phi_{g}=0.58[45,46]$.

Our system is polydisperse (BSA, $\mathrm{Na}^{+}$and $\mathrm{Cl}^{-}$particles have different size), so $\phi_{\max }$ of each lattice element will depend on its content. Since $\phi_{\max }$ estimation formula appears to only exist for the bi-disperse case in the published literature [47], here we use it under the assumption that $\mathrm{Na}^{+}$and $\mathrm{Cl}^{-}$can be reasonably treated as one species (compared to BSA):

$$
\begin{gathered}
\left.\phi_{\max }=\min \left(\frac{\phi_{\max \text { mono }}}{1-w \cdot\left(1-\phi_{\max m o n o}\right.}\right), \frac{\phi_{\max m o n o}}{w}\right), \\
w=\phi_{\text {large }} /\left(\phi_{\text {large }}+\phi_{\text {small }}\right),
\end{gathered}
$$

where $\phi_{\max \text { mono }}$ is the maximum packing fraction of a monodisperse system ( $\phi_{g}$ in this case), $\phi_{\text {large }}$ is the volume fraction of large particles, $\phi_{\text {small }}$ is the volume fraction of small particles.

Freedom of particle movement in a lattice element $(i, j, k)$ can be characterized as

$$
\Phi(i, j, k)=1-\frac{\phi_{\text {total }}(i, j, k)}{\phi_{\max }} .
$$

This value modulates the number of particles that can move between the lattice elements in a single simulation step, and is also used in the Krieger and Dougherty's semi-empirical formula [48] for calculating local viscosity of the dispersion:

$$
\mu(i, j, k)=\mu_{F} \cdot\left(1-\frac{\phi_{\text {total }}(i, j, k)}{\phi_{\max }}\right)^{-\phi_{\max }},
$$

where $\mu_{F}$ is the dynamic viscosity of the liquid.

In addition to fluid advection, the particles can also move between lattice elements due to diffusion. The diffusion coefficient $D_{p}$ for a spherical particle $p$ can be estimated from the Stokes-Einstein equation:

$$
D_{p}(i, j, k)=\frac{k_{B} \cdot T}{6 \pi \cdot \mu(i, j, k) \cdot r_{p}},
$$

where $k_{B}$ is the Boltzmann constant, $T$ is the temperature, $r_{p}$ is the Stokes particle radius.

\section{Calculation of the probability of particle motion}

When simulating random walk on a grid, during one simulation step a single particle may, with a certain probability $P$, move into one of the neighboring lattice elements or stay in place (mutually exclusive events). In the case of a large number of particles, these probabilities can be considered proportional to the amount of substance $\Delta n$ that has moved in the corresponding direction: 


$$
\frac{\Delta n(i, j, k, \Delta i, \Delta j, \Delta k)}{n(i, j, k)} \approx P(i, j, k, \Delta i, \Delta j, \Delta k),
$$

where $n(i, j, k)$ is the amount of substance in a lattice element with a three-dimensional index $(i, j, k)$, and $\Delta i, \Delta j, \Delta k \in\{-1,0,1\}$ denote the direction of particle movement.

For biased random walk, particle movement along the direction of the flow should be more likely than the movement in the opposite direction. Three methods for calculating the corresponding probabilities were considered.

\section{Particle motion probability calculation: method 1}

The first method was described in [34], where the probabilities of particle movement depended only on the velocity field:

$$
\begin{gathered}
P_{ \pm x}=\frac{1}{2 N}\left(1 \pm \frac{U_{x}}{U_{\max }}\right), \\
P_{ \pm y}=\frac{1}{2 N}\left(1 \pm \frac{U_{y}}{U_{\max }}\right), \\
P_{ \pm z}=\frac{1}{2 N}\left(1 \pm \frac{U_{z}}{U_{\max }}\right), \\
P_{w}=1-\left(P_{-x}+P_{+x}+P_{-y}+P_{+y}+P_{-z}+P_{+z}\right),
\end{gathered}
$$

where $P_{-x}, P_{+x}, P_{-y}, P_{+y}, P_{-z}, P_{+z}$ are the probabilities of movement in the direction of the corresponding axes, $P_{w}$ is the probability of the particle staying in place, $N=3$ is the dimensionality of space, $U_{x}, U_{y}, U_{z}$ are the components of the velocity field vector at a given point, $U_{\max }$ is the maximum projection of velocity in this simulation step.

To take into account the duration of the simulation step, the probabilities of transitions were calculated in the following way:

$$
\begin{aligned}
& P_{ \pm x}=\left(\frac{\Delta t \cdot\left|U_{x}(i, j, k)\right|}{L_{E}}\right) \cdot\left(\frac{1 \pm U_{x}(i, j, k) / U_{\max }}{6}\right), \\
& P_{ \pm y}=\left(\frac{\Delta t \cdot\left|U_{y}(i, j, k)\right|}{L_{E}}\right) \cdot\left(\frac{1 \pm U_{y}(i, j, k) / U_{\max }}{6}\right), \\
& P_{ \pm z}=\left(\frac{\Delta t \cdot\left|U_{z}(i, j, k)\right|}{L_{E}}\right) \cdot\left(\frac{1 \pm U_{z}(i, j, k) / U_{\max }}{6}\right), \\
& P_{\text {sum }}=P_{-x}+P_{+x}+P_{-y}+P_{+y}+P_{-z}+P_{+z}, \\
& P(i, j, k, \pm 1,0,0)=P_{ \pm x} / \max \left(P_{\text {sum }}, 1\right), \\
& P(i, j, k, 0, \pm 1,0)=P_{ \pm y} / \max \left(P_{\text {sum }}, 1\right), \\
& P(i, j, k, 0,0, \pm 1)=P_{ \pm z} / \max \left(P_{\text {sum }}, 1\right), \\
& P(i, j, k, 0,0,0)=1-\min \left(P_{\text {sum }}, 1\right),
\end{aligned}
$$

where $\Delta t$ is the simulation step duration, $L_{E}$ is the size of the lattice element.

\section{Particle motion probability calculation: method 2}

The idea of the second method was taken from the paper [35], according to which the probability of particle movement between lattice elements is proportional to the Boltzmann distribution: 


$$
P_{S} \propto \exp \left(-E_{S} / k_{B} T\right)
$$

where $P_{S}$ is the probability of finding a particle in the state $S, E_{S}$ is the energy of state $S$, $k_{B}$ is the Boltzmann constant, $T$ is the temperature, $\exp ()$ is the exponential function.

In this case, the $E_{S}$ corresponds to the work that a particle must perform against the Stokes' drag to move to a certain distance in a given direction:

$$
E_{S}(\vec{v})=-6 \pi \cdot \mu \cdot r_{p} \cdot(\vec{U} \cdot \vec{v}),
$$

where $\vec{U}$ is the vector of liquid velocity at a given point, $\vec{v}$ is the direction vector along which the particle may move during the simulation step $\Delta t$

$$
\vec{v}=\overrightarrow{\Delta i j k} \cdot(\Delta t \cdot|\vec{U}|),
$$

where $\overrightarrow{\Delta i j k}$ is the unit vector in the direction of the neighboring lattice element (or a zero vector in the case of the particle remaining in place).

Combining the equations (20-22), we obtain

$$
\begin{gathered}
P_{ \pm x}=C \cdot \exp \left( \pm \frac{6 \pi \mu r_{p} \cdot U_{x} \cdot\left(\Delta t \cdot\left|U_{x}\right|\right)}{k_{B} T}\right)=C \cdot \exp \left( \pm \frac{U_{x} \cdot\left(\Delta t \cdot\left|U_{x}\right|\right)}{D_{p}}\right) \\
P_{ \pm y}=C \cdot \exp \left( \pm \frac{6 \pi \mu r_{p} \cdot U_{y} \cdot\left(\Delta t \cdot\left|U_{y}\right|\right)}{k_{B} T}\right)=C \cdot \exp \left( \pm \frac{U_{y} \cdot\left(\Delta t \cdot\left|U_{y}\right|\right)}{D_{p}}\right) \\
P_{ \pm z}=C \cdot \exp \left( \pm \frac{6 \pi \mu r_{p} \cdot U_{z} \cdot\left(\Delta t \cdot\left|U_{z}\right|\right)}{k_{B} T}\right)=C \cdot \exp \left( \pm \frac{U_{z} \cdot\left(\Delta t \cdot \mid U_{z}\right)}{D_{p}}\right) \\
P_{w}=C \cdot \exp \left(\frac{6 \pi \mu r_{p} \cdot \vec{U} \cdot \overrightarrow{0}}{k_{B} T}\right)=C \cdot 1,
\end{gathered}
$$

where $P_{-x}, P_{+x}, P_{-y}, P_{+y}, P_{-z}, P_{+z}$ are the probabilities of movement in the direction of the corresponding axes, $P_{w}$ is the probability of the particle staying in place, $U_{x}, U_{y}, U_{z}$ are the components of the velocity field vector at a given point, $D_{p}$ is the diffusion coefficient at a given point, $C$ is an arbitrary constant. Accordingly,

$$
\begin{gathered}
P_{\text {sum }}=P_{-x}+P_{+x}+P_{-y}+P_{+y}+P_{-z}+P_{+z}+P_{w}, \\
P(i, j, k, \pm 1,0,0)=P_{ \pm x} / P_{\text {sum }}, \\
P(i, j, k, 0, \pm 1,0)=P_{ \pm y} / P_{\text {sum }}, \\
P(i, j, k, 0,0, \pm 1)=P_{ \pm z} / P_{\text {sum }}, \\
P(i, j, k, 0,0,0)=P_{w} / P_{\text {sum }} .
\end{gathered}
$$

\section{Particle motion probability calculation: method 3}

In the third method of probability calculation, a simplified geometric interpretation of particle motion was used (Fig. 3). Assuming that at a time $t$ the particles uniformly fill the volume $V_{E}=L_{E}{ }^{3}$ of the $(i, j, k)$ element, and during the simulation step $\Delta t$ their movement consists of translation along the fluid velocity vector $(\Delta t \cdot \vec{U})$ and random Brownian displacement (up to a distance $\sqrt{6 D_{p} \Delta t}$ ), then at the moment $t+\Delta t$ these particles will approximately occupy the cubic volume $V^{\prime}$ 


$$
V^{\prime} \approx\left(L_{E}+2 \sqrt{6 D_{p} \Delta t}\right)^{3}
$$

which will partially intersect with several lattice elements.

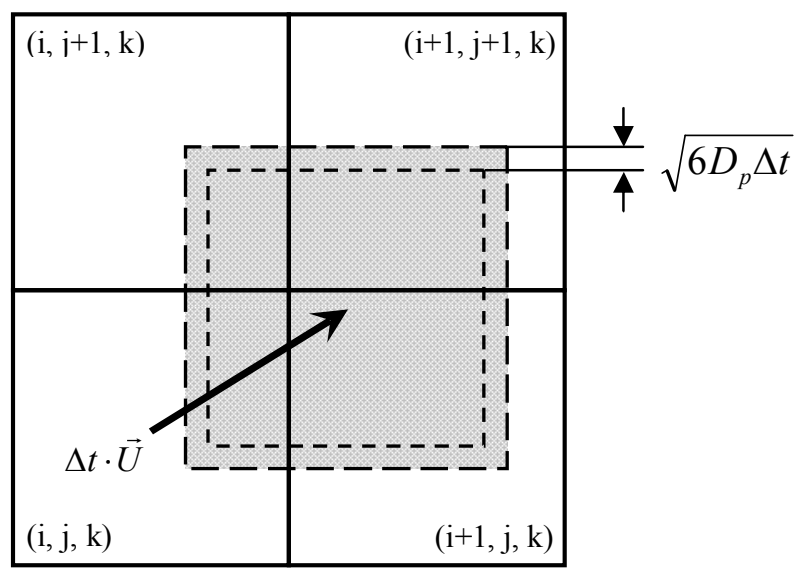

Fig. 3. Schematic illustration of particle motion in the third method of probability calculation.

Accordingly, the probability of particles to remain in the element $(i, j, k)$ or to move to a neighboring lattice element will be proportional to the volume of the intersection of the cube $V^{\prime}$ with the volume of the corresponding cubic element:

$$
\begin{gathered}
B_{ \pm x}=\max \left(L_{E} \cdot(\Delta i \pm 0.5), \Delta t \cdot U_{x} \pm \sqrt{6 D_{p} \Delta t}\right), \\
B_{ \pm y}=\max \left(L_{E} \cdot(\Delta j \pm 0.5), \Delta t \cdot U_{y} \pm \sqrt{6 D_{p} \Delta t}\right), \\
B_{ \pm z}=\max \left(L_{E} \cdot(\Delta k \pm 0.5), \Delta t \cdot U_{z} \pm \sqrt{6 D_{p} \Delta t}\right), \\
L_{x}=\max \left(B_{+x}-B_{-x}, 0\right), \\
L_{y}=\max \left(B_{+y}-B_{-y}, 0\right), \\
L_{z}=\max \left(B_{+z}-B_{-z}, 0\right), \\
P(i, j, k, \Delta i, \Delta j, \Delta k)=\frac{L_{x} \cdot L_{y} \cdot L_{z}}{V^{\prime}} .
\end{gathered}
$$

\section{Additional rules for calculating probabilities and redistribution of concentrations}

The following additional rules were also used in the modeling of particle redistribution.

In the case when a lattice element contains no water $(\alpha(i, j, k)=0)$, the particles of this element are only allowed to move vertically down (or remain in place, if $j=0$ ). It simulates the effect of gravity and prevents the movement of particles in completely dried regions.

On the boundaries of the computational domain, particle motion is limited by the corresponding boundary conditions (motion beyond the cell walls and the cell bottom is prohibited, and is reflected at the symmetry planes). Other types of particle interaction with the cell walls and bottom (e.g. sticking to the surface) were not modeled in this study.

Since particles can not move beyond the liquid-air boundary and should be less likely to move to densely packed lattice elements, the motion in the direction of the neighboring elements is also limited as follows:

$$
\begin{aligned}
& P^{\prime}(i, j, k, \Delta i, \Delta j, \Delta k)=\Phi(i+\Delta i, j+\Delta j, k+\Delta k) \times \\
& \quad \times \min (P(i, j, k, \Delta i, \Delta j, \Delta k), \alpha(i+\Delta i, j+\Delta j, k+\Delta k))
\end{aligned}
$$

where $\alpha$ is the amount of fluid in the element, $\Phi$ is the degree of mobility (14). 
After applying these rules, the probability sum can be less than one, so the probability of particles remaining in the element $(i, j, k)$ is recalculated as

$$
P^{\prime}(i, j, k, 0,0,0)=1-\sum_{\Delta i} \sum_{\Delta j} \sum_{\Delta k} P^{\prime}(i, j, k, \Delta i, \Delta j, \Delta k), \quad(\Delta i, \Delta j, \Delta k) \neq(0,0,0) .
$$

In the absence of an external electric field, the concentrations of $\mathrm{Na}^{+}$and $\mathrm{Cl}^{-}$ions, averaged over the volume of the cubic lattice element, can always be considered the same, so during the simulation, the redistribution of $\mathrm{Na}^{+}$and $\mathrm{Cl}^{-}$particles between the lattice elements was synchronized.

To prevent accumulation of rounding errors, at the end of each simulation step the amount of substance of BSA, $\mathrm{Na}^{+}$and $\mathrm{Cl}^{-}$in the lattice elements was normalized to maintain the total number of the corresponding particles.

\section{RESULTS AND DISCUSSION}

The course of liquid evaporation, obtained as a result of numerical simulation, is shown in Fig. 4-7. Until the surface of the liquid reached the bottom of the cell, the convective flows in the solution exhibit the character illustrated in Fig. 4: a diagonal flow from the corner to the center of the cell, as well as the circulation between the diagonal and the cell walls (spiraling toward the cell corner).

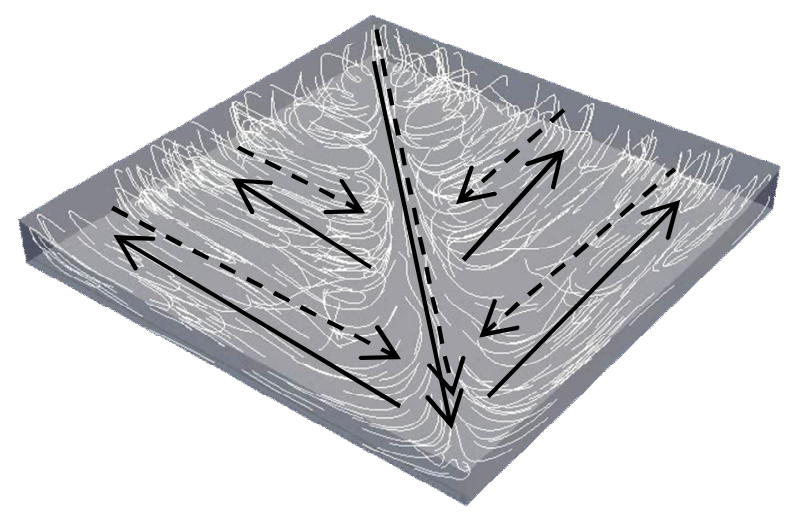

Fig. 4. Flow directions at the time $t_{\exp }=1$ hour $13 \mathrm{~min}$. Solid arrows denote the currents along the cell bottom, and dotted arrows denote the currents along the surface of the liquid.

As the evaporation progresses, the flow becomes more chaotic (Fig. 5a), but its general character is maintained almost up to $2 / 3$ of the total drying time (Fig. $5 b$ ).

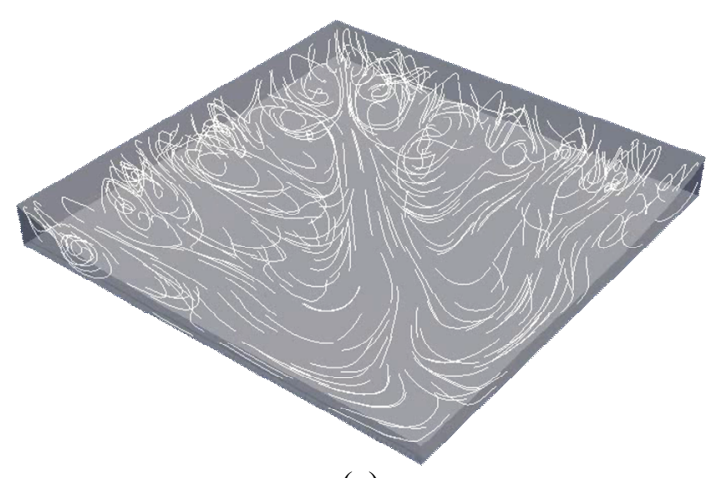

(a)

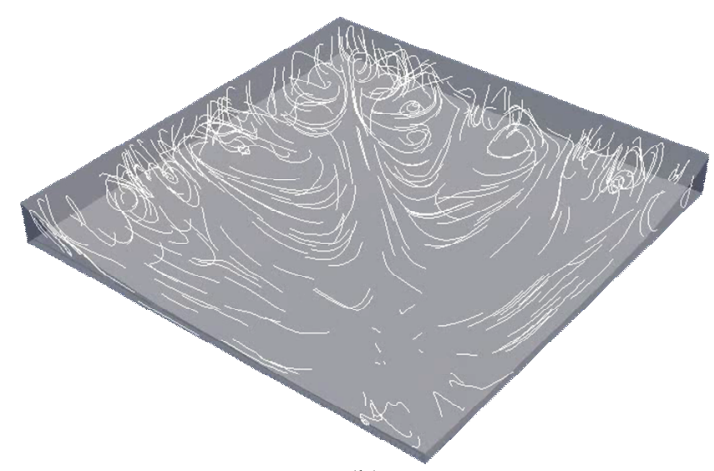

(b)

Fig. 5. Flow directions at the time (a) $t_{\exp }=1$ hour $36 \mathrm{~min}$, (b) $t_{\exp }=1$ hour $53 \mathrm{~min}$. 
When the liquid-air interface at a certain point reaches the cell bottom (Fig. 6a), the surface tension forces quickly withdraw the solution to the cell walls, although a small amount of liquid can remain as a drop in the center (Fig. 6b).

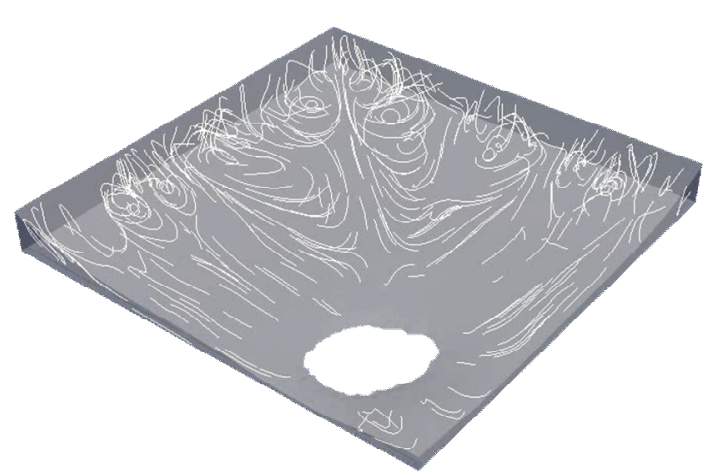

(a)

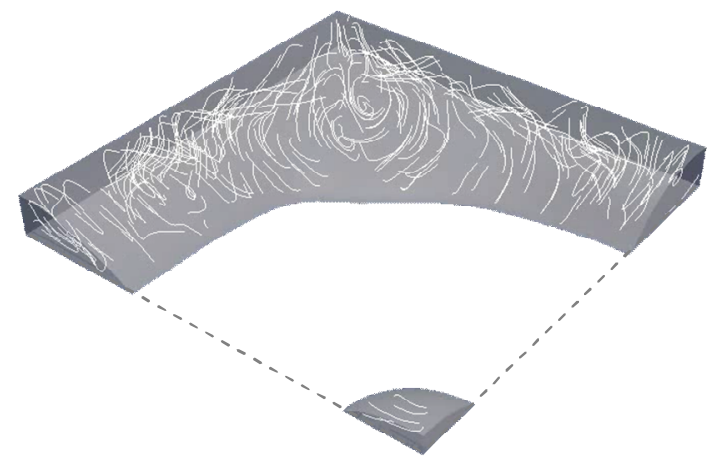

(b)

Fig. 6. Formation of a "hole" in the liquid surface (a), $t_{\exp }=1$ hour $54 \mathrm{~min}$;

the central part of the cell is left without liquid, except for a drop in the middle (b), $t_{\text {exp }}=1$ hour 56 min.

After this, the flows stabilize, resulting in a circulation between the cell bottom, the cell walls and the surface of the liquid (Fig. 7a), and the rest of the time the liquid dries toward the cell walls (Fig. 7b).

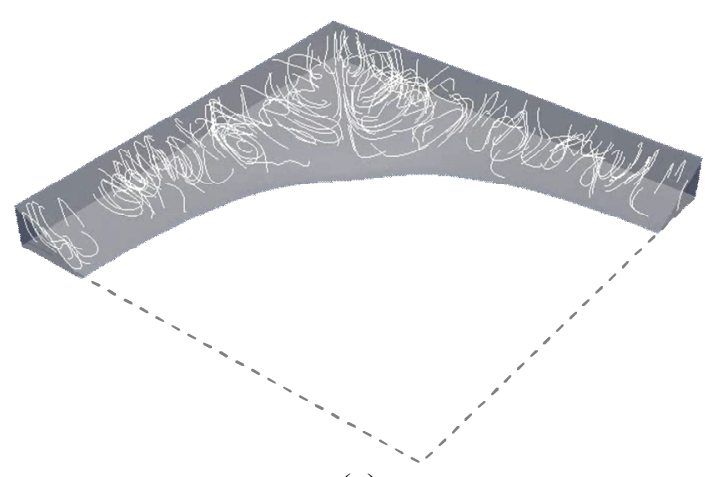

(a)

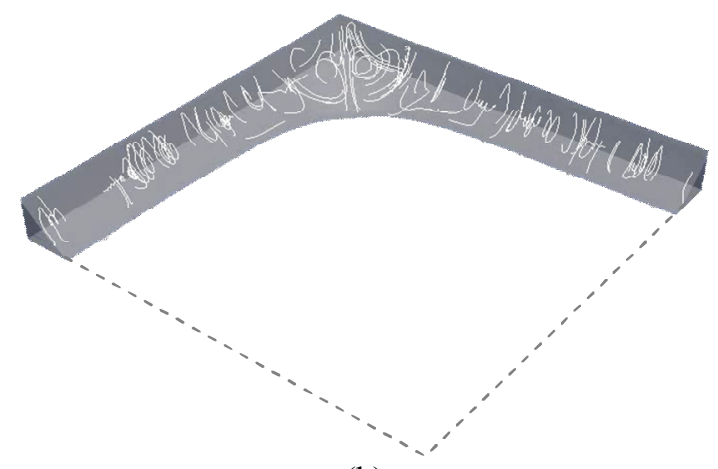

(b)

Fig. 7. Flow directions and fluid profile at the time (a) $t_{\exp }=2$ hours $19 \mathrm{~min}$, (b) $t_{\exp }=2$ hours $42 \mathrm{~min}$.

The distribution of protein and salt concentrations for the first method of probability calculation is shown in Fig. $8(\mathrm{a}, \mathrm{b})$, respectively. Since the probability of particle movement in this method depends only on the fluid velocity field, the resulting $\mathrm{BSA}$ and $\mathrm{NaCl}$ distributions are the same. At distances $<1 \mathrm{~mm}$ from the cell walls, there is an increased concentration of particles; at a distance of 1-3 mm from the walls (where the solution recedes after the "hole" is formed in the liquid surface), the distribution is slightly smaller and uneven; at a distance of 3-7 $\mathrm{mm}$ (the central part that quickly lost all the liquid) the distribution is relatively homogenous; finally, there is a diagonal strip of slightly lower concentration, which likely reflects the nature of the diagonal currents. 


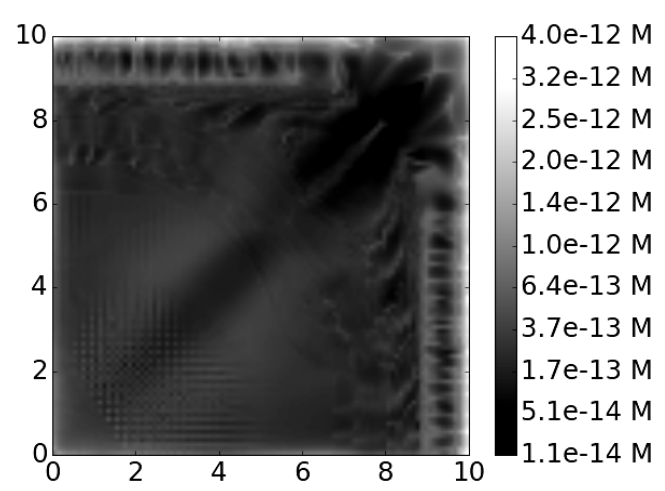

(a)

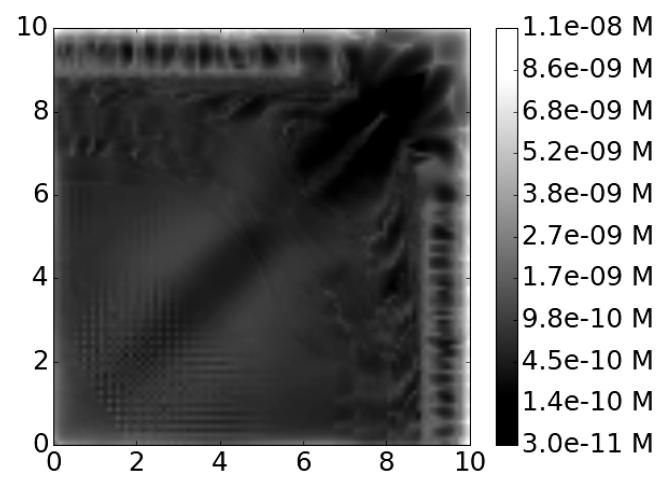

(b)

Fig. 8. Distribution of BSA (a) and $\mathrm{NaCl}$ (b) for the 1 st method of probability calculation.

Cell center is in the bottom left corner of the image.

The second (Fig. 9) and the third (Fig. 10) probability calculation methods take into account particle diffusivity, therefore they give slightly different and substantially less uniform distributions for protein and salt. Except for a few points at the cell walls with excessive concentration of particles, $\mathrm{BSA}$ and $\mathrm{NaCl}$ are mainly concentrated in a rounded band that is located at a distance of 1-3 mm from the cell walls. Unlike protein (Fig. 9a, 10a), a notable amount of salt is also uniformly present outside of this band (Fig. 9b, 10b), due to greater diffusivity of $\mathrm{NaCl}$ particles.

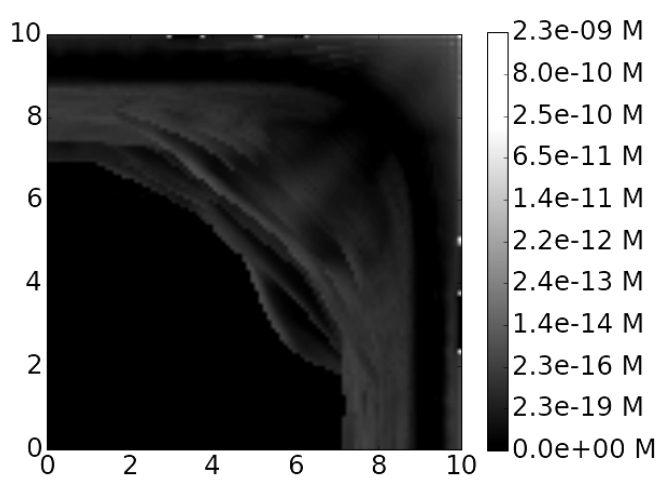

(a)

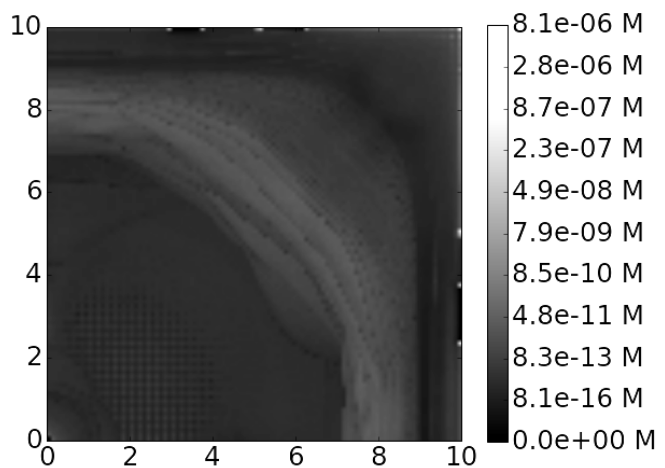

(b)

Fig. 9. Distribution of $\mathrm{BSA}$ (a) and $\mathrm{NaCl}$ (b) for the 2nd method of probability calculation. Cell center is in the bottom left corner of the image.

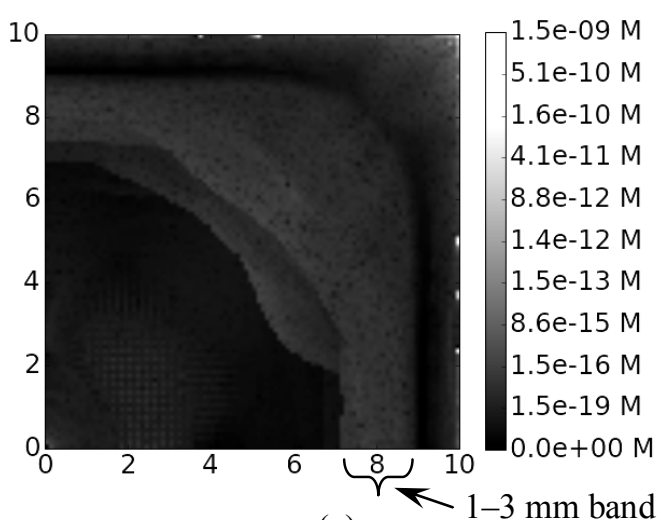

(a)

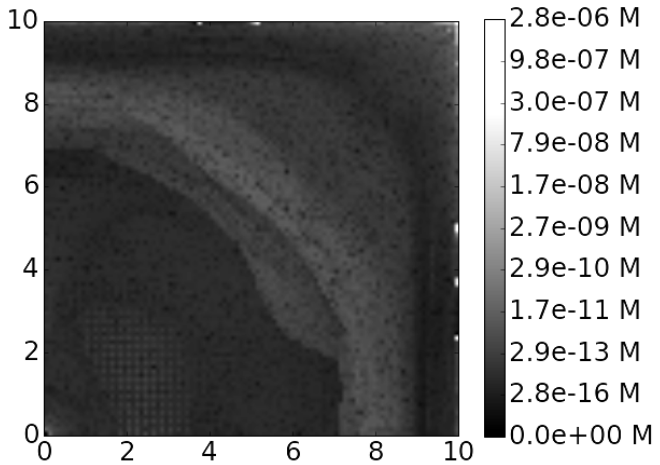

(b)

Fig. 10. Distribution of $\mathrm{BSA}(\mathrm{a})$ and $\mathrm{NaCl}$ (b) for the $3 \mathrm{rd}$ method of probability calculation. Cell center is in the bottom left corner of the image. 
Modeling of protein and salt redistribution during drying of a solution from a square cell

These results indicate that the weakness of method 1 (not accounting for particle diffusivity) is much more severe than the weakness of method 2 (exponential dependence of particle motion probability on the fluid velocity). Since method 3 lacks these disadvantages, we expect the results obtained with it to be the most accurate among the three.

Finally, comparing the results of the simulation with the experimental distributions of textures on films (Fig. 11a, 11b), and zigzag patterns (Z-patterns) in particular (Fig. 12b), the following observations can be made:

1. Textures stop forming at a distance of 1-1.5 $\mathrm{mm}$ from the cell edges, which approximately corresponds to the boundary of the 1-3 mm band in Fig. 9 and Fig. 10. Since pure salt solutions (without biopolymer) do not create textures [16], the simulation results suggest that very low BSA concentration between the 1-3 $\mathrm{mm}$ band and the cell walls is a likely reason for why textures do not cover the whole area of the cell.

2. Z-patterns (Fig. 12a) are concentrated approximately at the same distance from the cell edges as the distance to which the simulated liquid retreats after the "hole in water" is formed. Z-patterns are also practically absent in a small central part of the cell, which approximately corresponds to the droplet that separated from the main body of liquid (Fig. 12c). This suggests that rapid drying is one of the main prerequisites for the formation of Z-patterns.

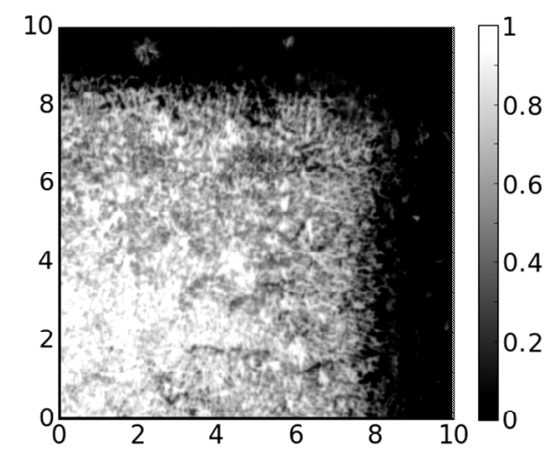

(a)

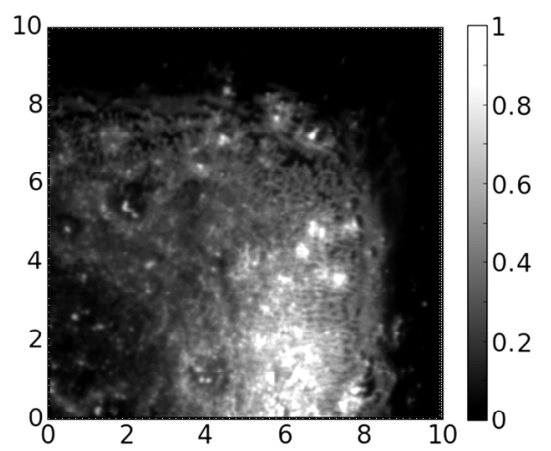

(b)

Fig. 11. Texture density distribution on the films of (a) $\mathrm{BSA}+\mathrm{NaCl}$ and (b) $\mathrm{HSA}+\mathrm{NaCl}$. Cell center is in the bottom left corner of the image.

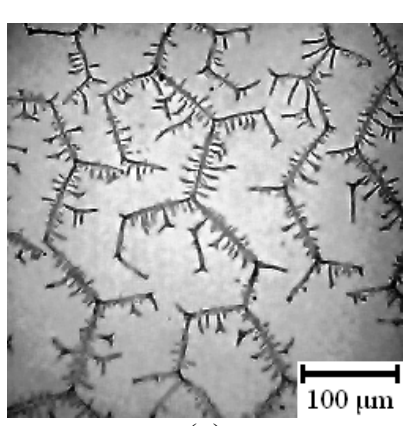

(a)

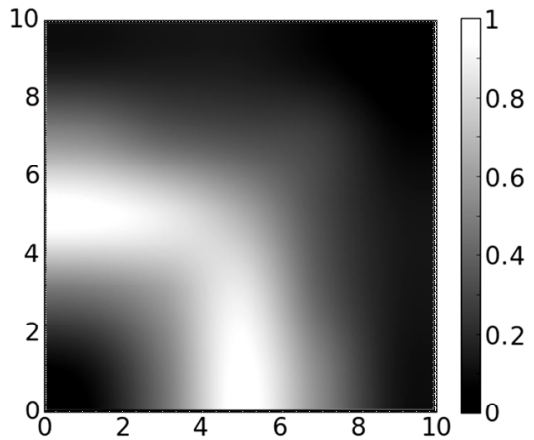

(b)

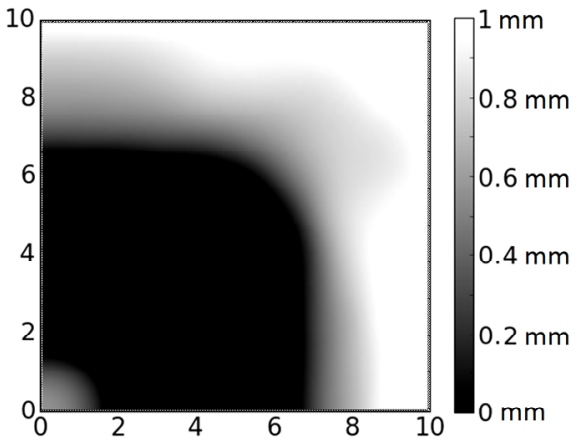

(c)

Fig. 12. (a) An example of zigzag patterns; (b) normalized interpolated distribution of zigzag pattern density on $\mathrm{BSA}+\mathrm{NaCl}$ films (symmetric averaging of 19 films [16-18]); (c) height-map of the liquid surface at the time $t_{\text {exp }}=1$ hour 56 min $35 \mathrm{~s}$. Cell center in (b) and (c) is in the bottom left corner of the image.

\section{CONCLUSIONS}

Thus, the distributions of BSA and $\mathrm{NaCl}$, obtained via a simulation of solution drying in a square cell, approximately correspond to the experimental texture distributions on the cell surface. The results support the hypotheses that the area of the textures depends on the local biopolymer concentration, and that zigzag patterns are formed in locations with high drying 
rate. In the future, we intend to combine fluid dynamics and particle motion and account for additional phenomena to improve the accuracy of the model.

\title{
ACKNOWLEDGEMENTS
}

This research did not receive any specific grant from funding agencies in the public, commercial, or not-for-profit sectors.

\section{CONFLICTS OF INTEREST}

The authors declare that they have no competing interests.

\author{
Author's ORCID ID \\ D.M. Glibitskiy (iD https://orcid.org/0000-0002-1000-7770
}

\section{REFERENCES}

1. Chen R., Zhang L., Zang D., Shen W. Blood Drop Patterns: Formation and Applications // Adv. Col. Interf. Sci. 2016. Vol. 231. P. 1-14. DOI: 10.1016/j.cis.2016.01.008

2. Brutin D., Sobac D., Loquet B., Sampol J. Pattern formation in drying drops of blood // J. Fluid Mech. 2011. Vol. 667. P. 85-95. DOI: $10.1017 /$ S0022112010005070

3. Killeen A. A., Ossina N., McGlennen R. C., Minnerath S., Borgos J., Alexandrov V., Sarvazyan A. Protein Self-Organization Patterns in Dried Serum Reveal Changes in B-Cell Disorders // Mol. Diagn. Ther. 2006. Vol. 10(6). P. 371-380. DOI: 10.1007/BF03256214

4. Kokornaczyk M. O., Dinelli G., Marotti I., Benedettelli S., Nani D., Betti L. Self-Organized Crystallization Patterns from Evaporating Droplets of Common Wheat Grain Leakages as a Potential Tool for Quality Analysis // Sci. World J. 2011. Vol. 11. P. 1712-1725. DOI: 10.1100/2011/937149

5. Busscher N., Kahl J., Andersen J. O., Huber M., Mergardt G., Doesburg P., Paulsen M., Ploeger A. Standardization of the Biocrystallization Method for Carrot Samples // Biol. Agric. Hortic. 2010. Vol. 27. P. 1-23. DOI: $10.1080 / 01448765.2010 .10510427$

6. Khatir N. M., Banihashemian S. M., Periasamy V., Majid W. H., Rahman S. A., Shahhosseini F. DNA Strand Patterns on Aluminium Thin Films // Sensors. 2011. Vol. 11. P. 6719-6727. DOI: 10.3390/s110706719

7. Dai S., Zhang X., Du Z., Dang H. Fabrication of nanopatterned DNA films by Langmuir-Blodgett technique // Mater. Lett. 2005. Vol. 59. P. 423-429. DOI: 10.1016/j.matlet.2004.09.038

8. Mayeres C. H., Lee S. A., Pinnick D. A., Carter B. J., Kim J. A study of Na-DNA films containing NaCl via scanning electron and tunneling microscopies // Biopolymers. 1995. Vol. 36. P. 669-673. DOI: 10.1002/bip.360360512

9. Lazar A. N., Shahgaldian P., Coleman A. W. Anion Recognition Effects in the Structuring of Bovine Serum Albumin Films // J. Supramol. Chem. 2001. Vol. 1. P. 193-199.

10. Chen G., Mohamed G. J. Complex protein patterns formation via salt-induced self-assembly and droplet evaporation // Eur. Phys. J. E. 2010. Vol. 33. P. 19-26. DOI: 10.1140/epje/i2010-10649-4

11. Sclavi B., Peticolas W. L., Powell J. W. Fractal-like patterns in DNA films, B form at $0 \%$ relative humidity, and antiheteronomous DNA: an IR study // Biopolymers. 1994. Vol. 34. P. 1105-1113.

12. Annarelli C. C., Reyes L., Fornazero J., Bert J., Cohen R., Coleman A. W. Ion and molecular recognition effects on the crystallisation of bovine serum albumin-salt mixtures // Cryst. Eng. 2000. Vol. 3. P. 173-194.

13. Gorr H. M., Zueger J. M., McAdams D. R., Barnard J. A. Salt-induced pattern formation in evaporating droplets of lysozyme solutions // Col. Surf. B: Biointerfaces. 2013. Vol. 103. P. 59-66. DOI: 10.1016/j.colsurfb.2012.09.043

14. Yakhno T. A. Sodium chloride crystallization from drying drops of albumin-salt solutions with different albumin concentrations // Tech. Phys. 2015. Vol. 60(11). P. 1601-1608. DOI: 10.1134/S1063784215110262

15. Glibitskiy G. M., Jelali V. V., Semenov M. O., Roshal A. D., Glibitskiy D. M., Volyanskiy O. Yu., Zegrya G. G. Interaction of DNA with Silver Nanoparticles // Ukr. J. Phys. 2012. Vol. 57(7). P. 695-699.

16. Glibitskiy G. M., Glibitskiy D. M., Gorobchenko O. A., Nikolov O. T., Roshal A. D., Semenov M. A., Gasan A. I. Textures on the surface of BSA films with different concentrations of sodium halides and water state in solution // Nanoscale Res. Lett. 2015. Vol. 10(1). Article ID 155. DOI: 10.1186/s11671-015-0860-0

17. Glibitskiy D. M., Gorobchenko O. A., Nikolov O. T., Cheipesh T. A., Roshal A. D., Zibarov A. M., Shestopalova A. V., Semenov M. A., Glibitskiy G. M. Effect of gamma-irradiation of bovine serum albumin solution on the formation of zigzag film textures // Rad. Phys. Chem. 2018. Vol. 144. P. 231-237. DOI: 10.1016/j.radphyschem.2017.08.019

18. Glibitskiy D. M., Gorobchenko O. A., Nikolov O. T., Shestopalova A. V., Semenov M. A. Characterization of zigzag patterns on the surface of bovine serum albumin films // Biophys. Bull. 2017. Vol. 37(1). P. 16-29. 
Modeling of protein and salt redistribution during drying of a solution from a square cell

19. Tarasevich Yu. Yu., Vodolazskaya I. V., Bondarenko O. P. Modeling of spatial-temporal distribution of the components in the drying sessile droplet of biological fluid // Col. Surf. A: Physicochem. Eng. Aspects. 2013. Vol. 432. P. 99-103.

20. Choudhury M. D., Dutta T., Tarafdar S. Pattern formation in droplets of starch gels containing $\mathrm{NaCl}$ dried on different surfaces // Col. Surf. A: Physicochem. Eng. Aspects. 2013. Vol. 432. P. 110-118. DOI: 10.1016/j.colsurfa.2013.04.064

21. Darwich S., Mougin K., Haidara H. From highly ramified, large scale dendrite patterns of drying " 'alginate/Au NPs" solutions to capillary fabrication of lab-scale composite hydrogel microfibers // Soft Mat. 2012. Vol. 8. P. 1155-1162. DOI: 10.1039/C1SM06623D

22. Raz E., Lipson E., Ben-Jacob E. New periodic morphologies observed during dentritic growth of ammonium chloride crystals in thin layers // J. Cryst. Growth. 1991. Vol. 108. P. 637-647. DOI: 10.1016/00220248(91)90243-X

23. Bhardwaj R., Fang X., Somasundaran P., Attinger D. Self-Assembly of Colloidal Particles from Evaporating Droplets: Role of DLVO Interactions and Proposition of a Phase Diagram // Langmuir. 2010. Vol. 26(11). P. 7833-7842. DOI: 10.1021/la9047227

24. Zhong X., Crivoi A., Duan F. Sessile nanofluid droplet drying // Adv. Col. Interf. Sci. 2015. Vol. 217. P. 1330. DOI: $10.1016 /$ j.cis.2014.12.003

25. Hua H., Larson R. G. Marangoni Effect Reverses Coffee-Ring Depositions // J. Phys. Chem. B. 2006. Vol. 110. P. 7090-7094. DOI: 10.1021/jp0609232

26. Nabil M., Rattner A. S. interThermalPhaseChangeFoam - A framework for two-phase flow simulations with thermally driven phase change // SoftwareX. 2016. Vol. 5. P. 216-226. DOI: 10.1016/j.softx.2016.10.002

27. Rattner A. S., Garimella S. Simple Mechanistically Consistent Formulation for Volume-of-Fluid Based Computations of Condensing Flows // J. Heat Transfer. 2014. Vol. 136. P. 071501-1-071501-9. DOI: $10.1115 / 1.4026808$

28. Engländer T., Wiegel D., Naji L., Arnold K. Dehydration of Glass Surfaces Studied by Contact Angle Measurements // J. Col. Interf. Sci. 1996. Vol. 179(2). P. 635-636. DOI: 10.1006/jcis.1996.0260

29. OpenFOAM v5 User Guide: 5.2 Boundaries. URL: https:/cfd.direct/openfoam/user-guide/boundaries/ (retrieved 2018-04-05).

30. Brackbill J. U., Kothe D. B., Zemach C. A continuum method for modeling surface-tension // J. Comput. Phys. 1992. Vol. 100(2). P. 335-354.

31. Wagner W., Pruss A. The IAPWS Formulation 1995 for the Thermodynamic Properties of Ordinary Water Substance for General and Scientific Use // J. Phys. Chem. Ref. Data. 2002. Vol. 31. P. 387-535.

32. Dean J. A., Lange N. A. Lange's Handbook of Chemistry. 15th edition. McGraw-Hill Professional, 1999. $1424 \mathrm{p}$.

33. Cox J. D., Wagman D. D., Medvedev V. A. CODATA - Key Values for Thermodynamics, aus der Reihe: CODATA, Series on Thermodynamic Properties. New York, Washington, Philadelphia, London : Hemisphere Publishing Corporation, 1989. $271 \mathrm{p}$.

34. Crivoi A., Duan F. Three-dimensional Monte Carlo model of the coffee-ring effect in evaporating colloidal droplets // Sci. Rep. 2014. Vol. 4. Article ID 4310. DOI: 10.1038/srep04310

35. Jung N., Seo H. W., Leo P. H., Kim J., Kim P., Yoo C. S. Surfactant effects on droplet dynamics and deposition patterns: A lattice gas model // Soft Mat. 2017. Vol. 13. P. 6529-6541. DOI: 10.1039/C7SM01224A.

36. Jachimska B., Pajor A. Physico-chemical characterization of bovine serum albumin in solution and as deposited on surfaces // Bioelectrochem. 2012. Vol. 87. P. 138-146. DOI: 10.1016/j.bioelechem.2011.09.004

37. Putnam F. W. The Plasma Proteins: Structure, Function and Genetic Control. Vol. 1. 2nd ed. New York : Acad. Press, 1975. 497 p.

38. Wise S. A., Watters R. L. Bovine Serum Albumin (7\% Solution). Certificate of Analysis // United States National Institute of Standards \& Technology. URL: https:/www-s.nist.gov/srmors/certificates/927d.pdf (retrieved 2010-06-30).

39. Hussain A. A., Abashar M. E. E., Al-Mutaz I. S. Effect of Ion Sizes on Separation Characteristics of Nanofiltration Membrane Systems // J. King Saud Univ. 2006. Vol. 19. Eng. Sci. 1. P. 1-19.

40. Bondi A. Van der Waals Volumes and Radii // J. Phys. Chem. 1964. Vol. 68(3). P. 441-451. DOI: $10.1021 / \mathrm{j} 100785 \mathrm{a} 001$

41. Meija J., Coplen T. B., Berglund M., Brand W. A., De Bièvre P., Gröning M., Holden N. E., Irrgeher J., Loss R. D., Walczyk T., Prohaska T. Atomic weights of the elements 2013 (IUPAC Technical Report) // Pure Appl. Chem. 2016. Vol. 88(3). P. 265-291. DOI: 10.1515/pac-2015-0305

42. Buscall R., D’Haene P., Mewis J. Maximum density for flow of dispersions of near monodisperse sphericalparticles // Langmuir. 1994. Vol. 10. P. 1439-1441. DOI: 10.1021/la00017a020

43. Pusey P. N., van Megen W. Phase behavior of concentrated suspensions of nearly hard colloidal spheres // Nat. 1986. Vol. 320. P. 340-342. DOI: 10.1038/320340a0 
44. van Megen W., Underwood S. M. Glass transition in colloidal hard spheres: Measurement and modecoupling-theory analysis of the coherent intermediate scattering function // Phys. Rev. E. 1994. Vol. 49. P. 4206-4220. DOI: 10.1103/PhysRevE.49.4206

45. Meeker S. P., Poon W. C. K., Pusey P. N. Concentration dependence of the low-shear viscosity of suspensions of hard-sphere colloids // Phys. Rev. E. 1997. Vol. 55. P. 5718-5722. DOI: 10.1103/PhysRevE.55.5718

46. Phan S.-E., Russel W. B., Cheng Z., Zhu J. Phase transition, equation of state, and limiting shear viscosities of hard sphere dispersions // Phys. Rev. E. 1996. Vol. 54. P. 6633-6645. DOI: 10.1103/PhysRevE.54.6633

47. Farr R. S., Groot R. D. Close packing density of polydisperse hard spheres // J. Chem. Phys. 2009. Vol. 131. P. 244104. DOI: 10.1063/1.3276799

48. Krieger I. M., Dougherty T. J. A mechanism for non-Newtonian flow in suspensions of rigid spheres // Trans. Soc. Rheol. 1959. Vol. 3. P. 137-152. DOI: 10.1122/1.548848

\section{REFERENCES}

1. Chen, R., Zhang, L., Zang, D., \& Shen, W. (2016). Blood Drop Patterns: Formation and Applications. Advances in Colloid and Interface Science, 231, 1-14. doi: 10.1016/j.cis.2016.01.008

2. Brutin, D., Sobac, D., Loquet, B., \& Sampol, J. (2011). Pattern formation in drying drops of blood. Journal of Fluid Mechanics, 667, 85-95. doi: 10.1017/S0022112010005070

3. Killeen, A. A., Ossina, N., McGlennen, R. C., Minnerath, S., Borgos, J., Alexandrov, V., \& Sarvazyan, A. (2006). Protein Self-Organization Patterns in Dried Serum Reveal Changes in B-Cell Disorders. Molecular Diagnosis \& Therapy, 10(6), 371-380. doi: 10.1007/BF03256214

4. Kokornaczyk, M. O., Dinelli, G., Marotti, I., Benedettelli, S., Nani, D., \& Betti, L. (2011). Self-Organized Crystallization Patterns from Evaporating Droplets of Common Wheat Grain Leakages as a Potential Tool for Quality Analysis. The Scientific World Journal, 11, 1712-1725. doi: 10.1100/2011/937149

5. Busscher, N., Kahl, J., Andersen, J. O., Huber, M., Mergardt, G., Doesburg, P., ...Ploeger A. (2010). Standardization of the Biocrystallization Method for Carrot Samples. Biological Agriculture and Horticulture, 27, 1-23. doi: 10.1080/01448765.2010.10510427

6. Khatir, N. M., Banihashemian, S. M., Periasamy, V., Majid, W. H., Rahman, S. A., \& Shahhosseini, F. (2011). DNA Strand Patterns on Aluminium Thin Films. Sensors, 11, 6719-6727. doi: 10.3390/s110706719

7. Dai, S., Zhang, X., Du, Z., \& Dang, H. (2005). Fabrication of nanopatterned DNA films by LangmuirBlodgett technique. Materials Letters, 59, 423-429. doi: 10.1016/j.matlet.2004.09.038

8. Mayeres, C. H., Lee, S. A., Pinnick, D. A., Carter, B. J., \& Kim, J. (1995). A study of Na-DNA films containing $\mathrm{NaCl}$ via scanning electron and tunneling microscopies. Biopolymers, 36, 669-673. doi: 10.1002/bip.360360512

9. Lazar, A. N., Shahgaldian, P., \& Coleman, A. W. (2001). Anion Recognition Effects in the Structuring of Bovine Serum Albumin Films. Journal of Supramolecular Chemistry, 1, 193-199.

10. Chen, G., \& Mohamed, G. J. (2010). Complex protein patterns formation via salt-induced self-assembly and droplet evaporation. European Physical Journal. E., 33, 19-26. doi: 10.1140/epje/i2010-10649-4

11. Sclavi, B., Peticolas, W. L., \& Powell, J. W. (1994). Fractal-like patterns in DNA films, B form at 0\% relative humidity, and antiheteronomous DNA: an IR study. Biopolymers, 34, 1105-1113.

12. Annarelli, C. C., Reyes, L., Fornazero, J., Bert, J., Cohen, R., \& Coleman, A. W. (2000). Ion and molecular recognition effects on the crystallisation of bovine serum albumin-salt mixtures. Crystal Engineering, 3, 173-194.

13. Gorr, H. M., Zueger, J. M., McAdams, D. R., \& Barnard, J. A. (2013). Salt-induced pattern formation in evaporating droplets of lysozyme solutions. Colloids and Surfaces B: Biointerfaces, 103, 59-66. doi: 10.1016/j.colsurfb.2012.09.043

14. Yakhno, T. A. (2015). Sodium chloride crystallization from drying drops of albumin-salt solutions with different albumin concentrations. Technical Physics, 60(11), 1601-1608. doi: 10.1134/S1063784215110262

15. Glibitskiy, G. M., Jelali, V. V., Semenov, M. O., Roshal, A. D., Glibitskiy, D. M., Volyanskiy, O. Yu., \& Zegrya, G. G. (2012). Interaction of DNA with Silver Nanoparticles. Ukrainian Journal of Physics, 57(7), 695-699.

16. Glibitskiy, G. M., Glibitskiy, D. M., Gorobchenko, O. A., Nikolov, O. T., Roshal, A. D., Semenov, M. A., \& Gasan, A. I. (2015). Textures on the surface of BSA films with different concentrations of sodium halides and water state in solution. Nanoscale Research Letters, 10(1), Article ID 155. doi: 10.1186/s11671-0150860-0

17. Glibitskiy, D. M., $\quad$ Gorobchenko, O. A., $\quad$ Nikolov, O. T., $\quad$ Cheipesh, T. A., $\quad$ Roshal, A. D., Zibarov, A. M., ...Glibitskiy G. M. (2018). Effect of gamma-irradiation of bovine serum albumin solution on the formation of zigzag film textures. Radiation Physics and Chemistry, 144, 231-237. doi: 10.1016/j.radphyschem.2017.08.019 
Modeling of protein and salt redistribution during drying of a solution from a square cell

18. Glibitskiy, D. M., Gorobchenko, O. A., Nikolov, O. T., Shestopalova, A. V., \& Semenov, M. A. (2017). Characterization of zigzag patterns on the surface of bovine serum albumin films. Biophysical Bulletin, 37(1), 16-29.

19. Tarasevich, Yu. Yu., Vodolazskaya, I. V., \& Bondarenko, O. P. (2013). Modeling of spatial-temporal distribution of the components in the drying sessile droplet of biological fluid. Colloids and Surfaces A: Physicochemical and Engineering Aspects, 432, 99-103.

20. Choudhury, M. D., Dutta, T., \& Tarafdar, S. (2013). Pattern formation in droplets of starch gels containing $\mathrm{NaCl}$ dried on different surfaces. Colloids and Surfaces A: Physicochemical and Engineering Aspects, 432, 110-118. DOI: 10.1016/j.colsurfa.2013.04.064

21. Darwich, S., Mougin, K., \& Haidara, H. (2012). From highly ramified, large scale dendrite patterns of drying "alginate/Au NPs" solutions to capillary fabrication of lab-scale composite hydrogel microfibers. Soft Matter, 8, 1155-1162. doi: 10.1039/C1SM06623D

22. Raz, E., Lipson, E., \& Ben-Jacob, E. (1991). New periodic morphologies observed during dentritic growth of ammonium chloride crystals in thin layers. Journal of Crystal Growth, 108, 637-647. doi: 10.1016/00220248(91)90243-X

23. Bhardwaj, R., Fang, X., Somasundaran, P., \& Attinger, D. (2010). Self-Assembly of Colloidal Particles from Evaporating Droplets: Role of DLVO Interactions and Proposition of a Phase Diagram. Langmuir, 26(11), 7833-7842. doi: 10.1021/la9047227

24.Zhong, X., Crivoi, A., \& Duan, F. (2015). Sessile nanofluid droplet drying. Advances in Colloid and Interface Science, 217, 13-30. doi: 10.1016/j.cis.2014.12.003

25. Hua, H., \& Larson, R. G. (2006). Marangoni Effect Reverses Coffee-Ring Depositions. Journal of Physical Chemistry B, 110, 7090-7094. doi: 10.1021/jp0609232

26. Nabil, M., \& Rattner, A. S. (2016). interThermalPhaseChangeFoam - A framework for two-phase flow simulations with thermally driven phase change. SoftwareX, 5, 216-226. doi: 10.1016/j.softx.2016.10.002

27. Rattner, A. S., \& Garimella, S. (2014). Simple Mechanistically Consistent Formulation for Volume-of-Fluid Based Computations of Condensing Flows. Journal of Heat Transfer, 136, 071501-1-071501-9. doi: $10.1115 / 1.4026808$

28. Engländer, T., Wiegel, D., Naji, L., \& Arnold, K. (1996). Dehydration of Glass Surfaces Studied by Contact Angle Measurements. Journal of Colloid and Interface Science, 179(2), 635-636. doi: 10.1006/jcis. 1996.0260

29. OpenFOAM v5 User Guide: 5.2 Boundaries. Retrieved from https://cfd.direct/openfoam/userguide/boundaries/

30. Brackbill, J. U., Kothe, D. B., \& Zemach, C. (1992). A continuum method for modeling surface-tension. Journal of Computational Physics, 100(2), 335-354.

31. Wagner, W., \& Pruss, A. (2002). The IAPWS Formulation 1995 for the Thermodynamic Properties of Ordinary Water Substance for General and Scientific Use. Journal of Physical and Chemical Reference Data, 31, 387-535.

32. Dean, J. A., \& Lange, N. A. (1999). Lange's Handbook of Chemistry (15th ed.). New York, N.Y.: McGrawHill Professional.

33. Cox, J. D., Wagman, D. D., \& Medvedev, V. A. (1989). CODATA - Key Values for Thermodynamics, aus der Reihe: CODATA, Series on Thermodynamic Properties. New York, Washington, Philadelphia, London: Hemisphere Publishing Corporation.

34. Crivoi, A., \& Duan, F. (2014). Three-dimensional Monte Carlo model of the coffee-ring effect in evaporating colloidal droplets. Scientific Reports, 4, Article ID 4310. doi: 10.1038/srep04310

35. Jung, N., Seo, H. W., Leo, P. H., Kim, J., Kim, P., \& Yoo, C. S. (2017). Surfactant effects on droplet dynamics and deposition patterns: A lattice gas model. Soft Matter, 13, 6529-6541. doi: 10.1039/C7SM01224A.

36. Jachimska, B., \& Pajor, A. (2012). Physico-chemical characterization of bovine serum albumin in solution and as deposited on surfaces. Bioelectrochemistry, 87, 138-146. doi: 10.1016/j.bioelechem.2011.09.004

37. Putnam, F. W. (1975). The Plasma Proteins: Structure, Function and Genetic Control. Vol. 1 (2nd ed). New York: Acad. Press.

38. Wise, S. A., \& Watters, R. L. (2014). Bovine Serum Albumin (7\% Solution). Certificate of Analysis. United States National Institute of Standards \& Technology. Retrieved from https://wwws.nist.gov/srmors/certificates/927d.pdf

39. Hussain, A. A., Abashar, M. E. E., \& Al-Mutaz, I. S. (2006). Effect of Ion Sizes on Separation Characteristics of Nanofiltration Membrane Systems. Journal of King Saud University, 19, Eng. Sci. 1. 1-19.

40. Bondi, A. (1964). Van der Waals Volumes and Radii. Journal of Physical Chemistry, 68(3), 441-451. doi: 10.1021/j100785a001 
41. Meija, J., Coplen, T. B., Berglund, M., Brand, W. A., De Bièvre, P., Gröning, M., ...Prohaska, T. (2016). Atomic weights of the elements 2013 (IUPAC Technical Report). Pure and Applied Chemistry, 88(3), 265-291. doi: 10.1515/pac-2015-0305

42. Buscall, R., D’Haene, P., \& Mewis, J. (1994). Maximum density for flow of dispersions of near monodisperse spherical-particles. Langmuir, 10, 1439-1441. doi: 10.1021/la00017a020

43. Pusey, P. N., \& van Megen, W. (1986). Phase behavior of concentrated suspensions of nearly hard colloidal spheres. Nature, 320, 340-342. doi: 10.1038/320340a0

44. Megen, W. van, \& Underwood, S. M. (1994). Glass transition in colloidal hard spheres: Measurement and mode-coupling-theory analysis of the coherent intermediate scattering function. Physical Review E, 49, 42064220. doi: 10.1103/PhysRevE.49.4206

45. Meeker, S. P., Poon, W. C. K., \& Pusey, P. N. (1997). Concentration dependence of the low-shear viscosity of suspensions of hard-sphere colloids. Physical Review E, 55, 5718-5722. doi: 10.1103/PhysRevE.55.5718

46. Phan, S.-E., Russel, W. B., Cheng, Z., \& Zhu, J. (1996). Phase transition, equation of state, and limiting shear viscosities of hard sphere dispersions. Physical Review E, 54, 6633-6645. doi: 10.1103/PhysRevE.54.6633

47. Farr, R. S., \& Groot, R. D. (2009). Close packing density of polydisperse hard spheres. Journal of Chemical Physics, 131, 244104. doi: 10.1063/1.3276799

48. Krieger, I. M., \& Dougherty, T. J. (1959). A mechanism for non-Newtonian flow in suspensions of rigid spheres. Transactions of the Society of Rheology, 3, 137-152. doi: 10.1122/1.548848 